\title{
A study on shopping experiences of consumers in online shopping in Chennai city
}

\author{
S. Visakan \\ Research Scholar, Dept. of Management, Studies University of Madras, Chennai, Tamil Nadu, India
}

Corresponding Author:

Email: rajamagesh65@hotmail.com

\begin{abstract}
Online shopping atmosphere is thus having an ever increasing responsibility in creating and maintaining relation between retailers and consumers and providing exceptional shopping experiences to consumers. The convenience, interactivity, excitement and offers are online shopping experiences of consumes. Significant difference exists between socio-economic profile of consumers and shopping experiences of consumers in online shopping. The convenience, offers, excitement and interactivity are positively and significantly impacting satisfaction of consumers towards online shopping. Thus, the online retailers should give adequate convenience to consumers and improve interactivity between web applications and consumers. They must provide more shopping excitement and realistic offers to consumers for their online shopping to enhance satisfaction of online shopping consumers.
\end{abstract}

Keywords: Consumer, Online Shopping, Shopping Experience.

\section{Introduction}

Online shopping is rapidly emergent phenomenon in across the globe, in specifically among nations having advanced information and communication technologies for marketing functions via the internet. Currently, internet is not only a networking and communication platform, but also a global ways of doing business. The usage of Internet has increasing remarkably over the last two decades and it is becoming a widespread ways for information search, marketing of products and services and trade transactions across the nations (Delafrooz et al 2009).

Online shopping is the process in which consumers to purchase products and services through the internet (Chen and Chang, 2003). Online shopping is a format of electronic marketing that permits consumers to shop products and services directly from retailers by using web browser through Internet. Presently, a number of consumers engage in online shopping due to its various benefits and getting new experiences in shopping through online platforms.

Online shopping atmosphere is thus having an ever increasing responsibility in creating and maintaining relation between retailers and consumers and providing exceptional shopping experiences to consumers (Koo et al 2008). The experiences in online shopping witnessed by consumers are highly associated with their satisfaction towards online shopping (Ratchford, et al 2001). Thus, it is imperative to study shopping experiences of consumers in online shopping in Chennai city.

\section{Materials and Method}

The present study is done Chennai city. The convenience sampling method is used to choose consumers of online shopping for this study. The structured questionnaire is used to collect data from 711 consumers of online shopping. The percentages are calculated to know socio-economic profile of consumers of online shopping. An exploratory factor analysis is done to study the shopping experiences of consumers in online shopping. The t-test and F-test are carried out to examine difference between shopping experiences of consumers in online shopping and socioeconomic profile of consumers. The multiple regression analysis is used to analyze the impact of online shopping experiences of consumers on their satisfaction about online shopping.

\section{Results}

Socio-economic profile of consumers of online shopping

The findings explain that 56.68 per cent of consumers of online shopping are males, whereas, 43.32 per cent of them are females and 46 per cent of consumers of online shopping have age group of 31 40 years, whereas 10.83 per cent of them have age group of above 50 years.

The findings make clear that 42.90 per cent of consumers of online shopping are under graduates, whereas, 8.72 per cent of them have secondary education and 33.90 per cent of consumers of online shopping are private employees, whereas, 12.52 per cent of them are retired.

The findings explicate that 30.38 per cent of consumers of online shopping belong to monthly income of Rs.30,001 - Rs.40,000, whereas, 12.80 per cent of them belong to monthly income of less than Rs.20,000 and 69.90 per cent of consumers of online shopping are married, whereas, 30.10 per cent of them are unmarried. 
Shopping experiences of consumers in online shopping

To study the shopping experiences of consumers in online shopping, an exploratory factor analysis is done and the results are shown in Table-1. Kaiser-MeyerOlkin (KMO test) measure of sampling adequacy $(\mathrm{KMO}=0.836)$ and Bartlett's test of Sphericity(Chi-
Square Value $=0.0014 ;$ significance $=0.000$ ) elucidate factor analysis method is suitable

Four experiences are derived which contribute for 88.15 per cent of variations on 20 variables and each of them shares 28.12 per cent, 23.48 per cent, 19.30 per cent and 17.25 per cent variation correspondingly.

Table 1: Shopping Experiences of Consumers in Online Shopping

\begin{tabular}{|c|c|c|c|c|c|c|}
\hline Experience & Variable & $\begin{array}{c}\text { Rotated } \\
\text { Factor } \\
\text { Loadings } \\
\end{array}$ & $\begin{array}{l}\text { Eigen } \\
\text { Value }\end{array}$ & $\begin{array}{c}\% \text { of } \\
\text { Variation }\end{array}$ & $\begin{array}{l}\text { Cronbach's } \\
\text { Alpha }\end{array}$ & $\begin{array}{l}\text { Experience } \\
\text { Name }\end{array}$ \\
\hline I & $\begin{array}{l}\text { I can shop round the clock } \\
\text { through online }\end{array}$ & 0.79 & \multirow{7}{*}{5.86} & \multirow{7}{*}{28.12} & & \multirow{7}{*}{ Convenience } \\
\hline & $\begin{array}{l}\text { Online shopping gives me } \\
\text { larger options }\end{array}$ & 0.72 & & & & \\
\hline & $\begin{array}{l}\text { I can find products which are } \\
\text { unavailable in offline stores }\end{array}$ & 0.76 & & & & \\
\hline & $\begin{array}{l}\text { Comparison of prices of } \\
\text { product in online sites is very } \\
\text { easy }\end{array}$ & 0.73 & & & & \\
\hline & $\begin{array}{l}\text { Online shopping is free from } \\
\text { physical irritations }\end{array}$ & 0.75 & & & & \\
\hline & $\begin{array}{l}\text { Online shopping is suitable to } \\
\text { my nature of occupation }\end{array}$ & 0.77 & & & & \\
\hline & $\begin{array}{l}\text { Online shopping fulfils my } \\
\text { taste and preference }\end{array}$ & 0.75 & & & 0.92 & \\
\hline \multirow[t]{6}{*}{ II } & $\begin{array}{l}\text { I can shop in response to } \\
\text { website ads }\end{array}$ & 0.70 & \multirow{6}{*}{3.72} & \multirow{6}{*}{23.48} & \multirow{6}{*}{0.89} & \multirow{6}{*}{ Interactivity } \\
\hline & $\begin{array}{l}\text { I have accessibility to } \\
\text { information about many } \\
\text { brands, when I shop through } \\
\text { online }\end{array}$ & 0.69 & & & & \\
\hline & $\begin{array}{l}\text { Online shopping procedures } \\
\text { are easier }\end{array}$ & 0.68 & & & & \\
\hline & $\begin{array}{l}\text { Online shopping provides } \\
\text { opinion of others }\end{array}$ & 0.71 & & & & \\
\hline & $\begin{array}{l}\text { Online shopping gives product } \\
\text { related information }\end{array}$ & 0.67 & & & & \\
\hline & $\begin{array}{l}\text { Online shopping gives updates } \\
\text { about the status of order }\end{array}$ & 0.74 & & & & \\
\hline \multirow[t]{4}{*}{ III } & $\begin{array}{l}\text { Online shopping is exciting } \\
\text { and entertaining }\end{array}$ & 0.66 & \multirow{4}{*}{1.65} & \multirow{4}{*}{19.30} & & \multirow{4}{*}{ Excitement } \\
\hline & $\begin{array}{l}\text { I enjoy creative sales } \\
\text { promotions of online retailers }\end{array}$ & 0.72 & & & & \\
\hline & $\begin{array}{l}\text { Online shopping gives } \\
\text { cheerfulness }\end{array}$ & 0.67 & & & & \\
\hline & $\begin{array}{l}\text { Online shopping are very } \\
\text { fascinating }\end{array}$ & 0.65 & & & 0.90 & \\
\hline \multirow[t]{3}{*}{ IV } & $\begin{array}{l}\text { Online shopping } \\
\text { special online offers }\end{array}$ & 0.65 & \multirow{3}{*}{1.03} & \multirow{3}{*}{17.25} & & \multirow{3}{*}{ Offers } \\
\hline & $\begin{array}{lcr}\text { Online } & \text { shopping } & \text { gives } \\
\text { discounts } & \text { during } \\
\text { seasons } & & \text { festival } \\
\end{array}$ & 0.70 & & & & \\
\hline & $\begin{array}{l}\text { Online shopping offers } \\
\text { different payment methods }\end{array}$ & 0.67 & & & 0.88 & \\
\hline
\end{tabular}




\begin{tabular}{|c|c|c|c|c|c|c|}
\hline & & & & & & \\
\hline & Cumulative \% of Variation & - & - & 88.15 & - & - \\
\hline & Overall & - & - & - & 0.90 & - \\
\hline
\end{tabular}

Method of Extraction: Principal Component Analysis

Method of Rotation: Varimax

Rotation converged in 10 iteration

Experience-I consists of I can shop round the clock through online, online shopping gives me larger options, I can find products which are unavailable in offline stores, comparison of prices of product in online sites is very easy, online shopping is free from physical irritations, online shopping is suitable to my nature of occupation and online shopping fulfils my taste and preference. Thus, this experience is named as Convenience.

Experience-II includes I can shop in response to website ads, I have accessibility to information about many brands, when I shop through online, online shopping procedures are easier, online shopping provides opinion of others, online shopping gives product related information and online shopping gives updates about the status of order. Hence, this experience is named as Interactivity.

Experience-III comprises of online shopping is exciting and entertaining, I enjoy creative sales promotions of online retailers, online shopping gives cheerfulness and online shopping are very fascinating. Therefore, this experience is named as Excitement.

Experience-IV encompasses online shopping provides special online offers, online shopping gives discounts during festival seasons and online shopping offers different payment methods. So this experience is named as Offers.

The overall Cronbach's Alpha value of the scale is 0.90 revealing that each measure is at acceptable level of internal consistency. Cronbach's Alpha value is differing from 0.92 for convenience to 0.88 for offers. The convenience, interactivity, excitement and offers are online shopping experiences of consumes.

Shopping experiences of consumers in online shopping and socio-economic profile of consumers

To examine difference between shopping experiences of consumers in online shopping and socioeconomic profile of consumers, the t-test and Analysis of Variance test were done and the results are shown in Table-2.

Table 2: Difference between Shopping Experiences of Consumers in Online Shopping and Socio-Economic Profile of Consumers

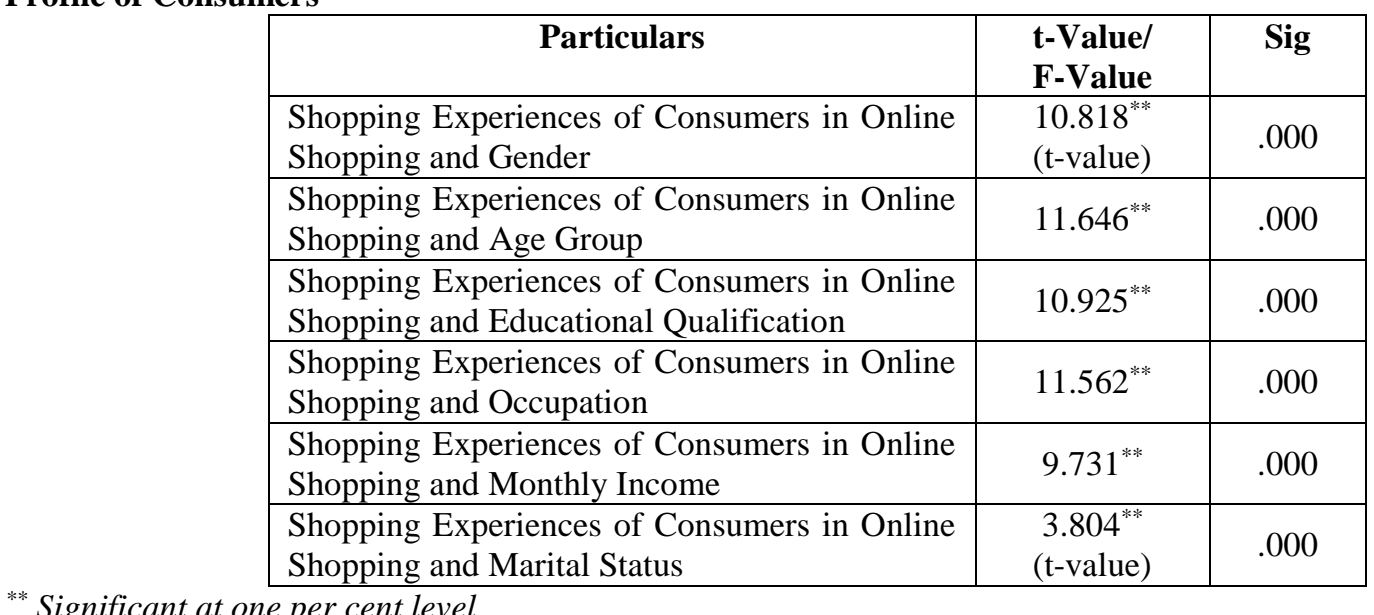

The F-values and t-values are significant at one per cent level explaining that significant difference is prevailing between shopping experiences of consumers in online shopping and socio-economic profile of consumers.

Impact of online shopping experiences of consumers on their satisfaction about online shopping

To analyze the impact of online shopping experiences of consumers on their satisfaction about online shopping, the multiple regression is done and the results are presented in Table-3. The coefficient of multiple determination $\left(\mathrm{R}^{2}\right)$ is 0.58 and adjusted $\mathrm{R}^{2}$ is 0.56 showing the regression model is good fit. It reveals that 56.00 per cent of the variation in dependent variable is shared by the independent variables. The Fvalue of 21.110 is statistically significant at one per cent level indicating the model is significant. 
Table 3: Impact of Online Shopping Experiences of Consumers on Their Satisfaction about Online Shopping

\begin{tabular}{|l|c|c|c|}
\hline $\begin{array}{c}\text { Online Shopping } \\
\text { Experience }\end{array}$ & $\begin{array}{c}\text { Regression } \\
\text { Coefficients }\end{array}$ & t-value & Sig \\
\hline Intercept & $1.147^{* *}$ & 9.185 & .000 \\
\hline Convenience $\left(\mathrm{X}_{1}\right)$ & $.454^{* *}$ & 6.536 & .000 \\
\hline Interactivity $\left(\mathrm{X}_{2}\right)$ & $.310^{* *}$ & 5.042 & .000 \\
\hline Excitement $\left(\mathrm{X}_{3}\right)$ & $.343^{* *}$ & 5.305 & .000 \\
\hline Offers $\left(\mathrm{X}_{4}\right)$ & $.392^{* *}$ & 5.714 & .000 \\
\hline $\mathrm{R}^{2}$ & 0.58 & & \\
\hline Adjusted $\mathrm{R}^{2}$ & 0.56 & & \\
\hline $\mathrm{F}$ & 21.110 & & .000 \\
\hline
\end{tabular}

${ }^{* *}$ Significance at one per cent level

The convenience, offers, excitement and interactivity have significant and positive impact on satisfaction of consumers about online shopping at one per cent level.

\section{Conclusion}

From the above findings, it is concluded that the convenience, interactivity, excitement and offers are experiences of consumes in online shopping. Significant difference prevails between socio-economic profile of consumers and shopping experiences of consumers in online shopping. The convenience, offers, excitement and interactivity are having significant and positive impact on satisfaction of consumers towards online shopping. Hence, the online retailers must provide greater convenience to consumers and improve interactivity between web and consumers. They should give more shopping excitement and reasonable offers to consumers for their online shopping in order to enhance satisfaction of online shopping consumers.

\section{References}

1. Chen, S. J., \& Chang, T. Z. (2003). A Descriptive Model of Online Shopping Process: Some Empirical Results. International Journal of Service Industry Management, 14 (5), 556 - 569.

2. Delafrooz, N., Paim, L. H., Haron, S. A., Sidin, S. M., \& Khatibi, A.(2009). Factors Affecting Students' Attitude toward Online Shopping. African Journal of Business Management, 3(5), 200 - 209.

3. Koo, D.M., Kim, J.J. \& Lee, S.W. (2008). Personal Values as Underlying Motives of Shopping Online. Asia Pacific Journal of Marketing and Logistics, 20(2), 156 173.

4. Ratchford, B. T., Talukdar, D., \& Lee, M. S. (2001). A Model of Consumer Choice of the Internet as an Information Source. International Journal of Electronic Commerce, 5(3), 7 - 22. 